\title{
Students' Perception of Home Economics Classroom Learning Environment in Edo State, Nigeria
}

\author{
B.E. Uwameiye \\ Department of Vocational \& Technical Education, Faculty of Education, Ambrose Alli \\ University, Ekpoma, Edo State, Nigeria
}

\begin{abstract}
This study examines students' perception of their home economics classroom learning environment. The population consisted of all students from public schools in Edo State. A systematic random sampling technique was utilized to select a total number of 540 students for the study an instrument titled "Perception of Students of Home Economics Classroom Learning Environment (PSHELE)" was utilized to gather data. Findings indicates that home economics teachers do not have good method of teaching, since they are unable to make home economics lessons attractive and interesting to students, teachers of home economics are unable to encourage, support and give roam for individual differences in the course of teaching their subject. Finally, home economics laboratories are not functional, equipment are not enough and those available are not maintained, no good lighting and students sometimes bring in equipment from home for home economics practical. Based on the findings, the following recommendations were proffered; that Government should provide furnished home economics laboratories in public secondary schools in Edo state, students should be motivated by their teachers to participate in home economics lessons and government should provide good learning environment in all public secondary schools.
\end{abstract}

\section{Introduction}

The policy underlying the 6:3:3:4 system of education in Nigeria is to enable students acquire knowledge and preliminary vocational training relevant to eventual self-reliance. The attainment of this policy would depend largely on the interaction between the learners (students) and the school environment; any shortfall from them may inhibit the students' overall learning outcome.

The student belongs to several environments such as the home, school and the community where he lives; all these contribute to their right to learn, develop and live. The term learning environment has been used by many writers.

Whereas some see learning environment as the physical characteristics of the school environment, others take it as the teaching staff, leadership styles, morals and co-operations among others. However, Burden and Fraser [3] sees it as the total learning environment where the child finds himself, which include the norms of the school system and the pattern of grouping of the learner for learning. This is why the classroom is a major component of the learning environment. Dorman et al. see the classroom as a critical place for pupils' interpersonal and educational development. In all, a good classroom is essential for effective learning to take place [4]. Goodlord noted that good classroom environments are those with adequate equipment for teaching and learning, with motivated teachers who use standard teaching methodologies and have adequate facilities. In other words, schools that do not meet this standard may not be able to provide good learning environment for proper leaning to take place [6].

This study was motivated by the desire to understand the perception of students of their classroom learning environment as an educational phenomenon, crucial to students' interest in school subjects. Home economics, an integrated subject having orientation of creativity, ought to be taught in the laboratory. However, most public secondary schools in Edo State are not properly quipped or nonexistent; as a result, the subject is mostly taught in normal classrooms. The study therefore attempt to assess student's perception of their home economics classroom learning environment in junior secondary schools of Edo State.

\section{Literature Review on Learning Environment}

All stakeholders in education desire a classroom in which the subject matter is relevant, learning is exciting and students are supported and encouraged to acquire new knowledge. There have been series of research on classroom as learning environment, quantitative and qualitative method have been utilized and a wide varieties of questionnaire have been developed and used for this purpose. Creating a successful classroom where learning is highly valued is the sole responsibility of the teacher. According to Willen, a major part of building a supportive climate for learning is the use of appropriate method of teaching school subjects.

Results of the current situation in Nigerian schools, shows that teachers favoured the use of 
lecture method for almost all subjects [8]. Also classroom observational studies have indicated that teachers' instructional methods were at variance with the method implied. This evidence was partly supported by Imariagbe [11] and Okeke [9] where it was revealed that the overall pattern of intellectual transactions in secondary schools in Nigeria was teacher dominated, extremely didactic and theoretical. The teacher only presented the facts and principles contained in the standard recommended textbooks and students were rarely involved in practical experiences other than very infrequent teacher demonstration experiments. This teaching approach differs substantially from what is obtained elsewhere.

Over the years the link between students' achievements and classroom learning has been researched into. Dorman et al. [4] writes that every school has a passive climate which has an influence on the behavior of both teachers and students to succeed in teaching and learning. If teachers have a supportive and conducive working environment, a better students' achievement will result.

In addition, Fisher et al. [5] adapted the learning model to give an indication that a teacher's interpersonal behaviour in the classroom significantly affects the performance of students in chemistry, which indicates that teachers' behavior influences students' outcomes. Home economics educationists have over the years advocated well equipped home economics laboratories for home economics practical classes which meet the yearning of students over the years [14].

Low enrolment in home economics and other school subjects have also been traced to the classroom learning environment. Oyedeji identified the classroom environment as the militating factor which constantly interact to generate or degenerate cognitive and affective readiness. In addition, Mba [15] identified the teacher factor as one of the problems of the low level of acceptance of home economics as a school subject. In her opinion, methods utilized by the teachers in home economics classrooms are obsolete and have rendered the subject uninteresting. According to Tanvi [18], the teacher, the way he teaches, instructional process, the way he/she manages the students during the teaching and learning process has effect on the students' learning outcome.

Level of performance among students in secondary schools has been fully linked to classroom environment variables. For instance, Koreau [13] and Nbina [16] indicated that poor physical structures such as classrooms, incompetent teachers and inadequate instructional materials were responsible for poor performance of students in most school subjects. Koreau [13] specifically identified variables such as, poor laboratories and uncondusive classrooms as some of the major causes of poor performance of students in schools.

\subsection{Statement of Problem}

Presently, enrolment of students into home economics related courses in the West Africa Examination Council (clothing and textiles, Home Management and Clothing and Textiles) have dwindled completely. Uko-Aviomoh [19] and Anene-Okeakwa [1] note that students have lost interest in home economics as a subject in secondary schools and are becoming fewer in the colleges of education, where teachers are trained as teachers for teaching in primary and junior secondary schools thereby jeopardizing the future of the subject. The problem statement stated in question form therefore, is "could the classroom learning environment in home economics be so discouraging to the extent that students are no longer encouraged to participate in the home economics lessons?"

\subsection{Purpose of Study}

The purpose of this study is to find out the students' perception of their home economics classroom learning environment in Edo State, Nigeria. Specifically, the purpose of this study is to find out:

- The perception of students in Edo State, Nigeria secondary schools about their home economics teachers methods of teaching;

- The perception of students in Edo State, Nigeria secondary schools about their home economics teacher disposition in class; and

- The perception of students in Edo State, Nigeria secondary schools about the facilities and equipment used in the teaching and learning of home economics.

\subsection{Research Questions}

This study answered the following research questions:

- What is the perception of students on their home economics teachers' method of teaching in Edo State, Nigeria secondary schools?

- What is the perception of students on their home economics teachers' disposition in the class in Edo State, Nigeria secondary schools?

- What is the perception of students about the facilities and equipment in the teaching and learning of home economics in Edo State, Nigeria secondary schools? 


\section{Methodology}

\subsection{Research Design}

The research design utilized in this study was a descriptive survey design which involved the collection of data in order to answer the research questions.

\subsection{Population}

The population for this study consisted of all junior secondary school students in public secondary schools in Edo state, Nigeria.

\subsection{Sample and Sampling Technique}

The sample for this study was obtained through random sampling of all junior secondary schools in Edo State. The state is made up of 18 local government areas and a total of 337 Junior secondary schools. Three secondary schools were randomly selected from each of the 18 local government areas through the balloting technique yielding a total of 36 schools. The stratified random sampling technique was used to select 15 students from any JSS 11 class per school yielding a total of 540 students that were utilized for the study.

\subsection{Research Instrument}

The questionnaire was the instrument used for data collection. The instrument utilized was a 19 item. It was adapted from the socio-cultural environment scale developed by Jegede, Fraser and (1990). The original 20 item socio-cultural environment scale with emphasis in science was reorganized by the researcher into 19 items using the three variables which are Teachers' methods of teaching, teachers' disposition in class and facilities and equipment for teaching home economics. Five of the 19 items are about the teacher disposition in class, seven of the items on the method of teaching, and six on the facilities. The 19 items were worded to reflect what respondents perceived about their home economics classroom environment.

Each question is a four point likert scale with responses ranging from "Strongly Agree" to Strongly Disagree". Strongly Agree and was scored 4, Agree 3, Disagree 2, and Strongly Disagree 1.

\subsection{Validity and Reliability of the Instrument}

The validity of the instrument was undertaken by home economics education experts. It was found to be valid test for assessing student's perception of home economics classroom environment. In addition to the face validity, the perception of 60 students who were not participating in the research were subjected to K-221 formula statistically and yielded reliability co-efficient of 0.60 .

\subsection{Method of Data Collection}

The researcher with the assistance of the home economics teachers in the selected schools administered the questionnaire on the students. The respondents filled the questionnaire in their various home economics classrooms. This took place during the normal class period and was returned at the end of the period.

\subsection{Method of Data Analysis}

The statistical technique used was the mean and standard deviation.

Table 3 reveals that equipment in the home economics laboratory are not functional (1.88); there are no good lightings and functional air conditioners (2.02); students bring in equipment from home to carryout practical lessons (1.02); the laboratory is not equipped with modern facilities (1.12); the equipment available is not maintained (1.22); and the classrooms available are not comfortable (1.04).

\section{Findings}

Findings of this study are summarized as follows: 1. Home economics teachers do not have good method of teaching, since they are unable to make home economics lessons attractive and interesting to students

2. Teachers of home economics are unable to encourage, support and give room for individual differences in the course of teaching their subject

3. Home economics laboratories are not functional, equipment are not enough and those available are not maintained, no good lighting and students sometimes bring in equipments from home for home economics practical.

\subsection{Discussion of Findings}

Table 1 indicated that home economics teachers in Edo State Nigeria do not have good method of teaching, since they are unable to make home economics lessons attractive and interesting to students. This finding is supported by Okeke [9] and Mba [15] who identified the teacher factor as the problem of home economics In their opinion, methods used by the teacher are obsolete and uninteresting. Poor quality teaching is a problem that can adversely affect learners. Anyankoha makes it clear that what students learn cannot go beyond what their teacher are able to present to them. If teachers 
are weak in content, knowledge and pedagogical competence which are so vital for effective learning to take place, then the learning outcome will equally be weak.

Table 1. Method of Teaching

\begin{tabular}{|l|l|l|l|l|}
\hline SN & STATEMENT & X & SD & DECISION \\
\hline 1 & $\begin{array}{l}\text { Teachers of home economics gives students opportunity to participate in } \\
\text { home economics lessons }\end{array}$ & 2.02 & 0.77 & Disagree \\
\hline 2 & $\begin{array}{l}\text { Teachers of home economics allow students to learn new skills at their own } \\
\text { ability }\end{array}$ & 1.01 & 0.06 & Disagree \\
\hline 3 & $\begin{array}{l}\text { Practical lessons are demonstrated by home economics teacher before } \\
\text { students practice them }\end{array}$ & 1.41 & 0.06 & Disagree \\
\hline 4 & $\begin{array}{l}\text { Teachers of home economics use different ways to make students } \\
\text { understandhome economics topics }\end{array}$ & 1.20 & 0.81 & Disagree \\
\hline 5 & Teachers of home economics teach well & 1.82 & 0.53 & Disagree \\
\hline 6 & Lessons taught by home economics teachers are interesting & 1.71 & 0.87 & \\
\hline 7 & $\begin{array}{l}\text { Teacher allow students to ask questions when they do not understand } \\
\text { Agree }\end{array}$ & 3.02 & 0.97 & Disagree \\
\hline
\end{tabular}

Table 2. Home Economics Teachers Disposition in Class

\begin{tabular}{|c|c|c|c|c|}
\hline SN & STATEMENT & $\mathrm{X}$ & SD & DECISION \\
\hline 1 & Teacher supports students through their practical lessons & 3.22 & 0.81 & Agree \\
\hline 2 & Teacher provide projects that encourages co operative group work & 1.45 & 0.66 & Disagree \\
\hline 3 & $\begin{array}{l}\text { Teacher inform students of their expectation of students achievements in } \\
\text { home economics lessons }\end{array}$ & 1.01 & 0.87 & Disagree \\
\hline 4 & $\begin{array}{l}\text { Teacher allows students to work at their own pace in home economics } \\
\text { class }\end{array}$ & 2.01 & 0.81 & Disagree \\
\hline 5 & $\begin{array}{l}\text { Teacher of home economics is warm and receptive in home economics } \\
\text { class }\end{array}$ & 1.03 & 0.82 & Disagree \\
\hline & Grand Mean & 1.65 & 0.87 & Disagree \\
\hline
\end{tabular}

Table 3: Facilities and Equipment Used for Teaching and Learning Home Economics

\begin{tabular}{|l|l|l|l|l|}
\hline SN & STATEMENT & $\mathrm{X}$ & SD & DECISION \\
\hline 1 & Equipments in the home economics laboratory are functional & 1.88 & 0.96 & Disagree \\
\hline 2 & $\begin{array}{l}\text { The home economics laboratory has good lightings and functional } \\
\text { airconditioners }\end{array}$ & 2.02 & 0.77 & Disagree \\
\hline 3 & Students do not need to bring equipment from home for practical lessons & 1.02 & 0.76 & Disagree \\
\hline 4 & The home economics laboratory is equipped with modern facilities & 1.12 & 0.97 & Disagree \\
\hline 5 & $\begin{array}{l}\text { The equipment in Home economics are maintained and repaired when } \\
\text { they go bad }\end{array}$ & 1.22 & 0.87 & Disagree \\
\hline 6 & Each topic taught always has facilities available to practicalize them & 1.42 & 0.89 & Disagree \\
\hline 7 & $\begin{array}{l}\text { Adequate and comfortable classroom are available for home economics } \\
\text { lessons }\end{array}$ & 1.04 & 0.89 & Disagree \\
\hline & Grand Mean & 1.39 & 0.83 & Disagree \\
\hline
\end{tabular}

This finding is also consistent with Willen who sees the use of good method of teaching as a supportive climate for learning. Furthermore, Imariagbe [11] and, Okeke [9] corroborated this finding when they reported that the overall pattern of intellectual transactions in secondary school environment was 
teacher dominated and extremely didactic and theoretical. That most teachers only presented the facts and principles contained in the standard recommended textbooks and students were rarely involved in practical experiences other than very infrequent teacher demonstration experiments. This teaching approach was highly condemned.

Findings from this study also indicate that teachers of home economics are unable to encourage, support and give roam for individual differences in the course of teaching their subject. This is supported by Okeke [9] who found that teachers quality is the major problem of home economics. Teachers of home economics need to create warm atmosphere in their class lessons to elicit the interest of the students without which the students will not learn properly. Several factors may be responsible for teachers' disposition in class. This finding is further strengthened by Hughes, who makes it clear that every school has a passive climate which has an influence on the behavior of both teachers and students. However, teachers should provide supportive and conducive learning environment for effective teaching and learning to take place in schools,

Table 3 points out that home economics laboratories are not functional, equipment are not enough and those available are not maintained, no good lighting and students sometimes bring in equipments from home for home economics practical. This finding is supported by Ogwo and Oranu [8], who found out that inadequate instructional materials and unwillingness of the teacher to improvise is a great impediment to the effective teaching and learning of home economics. This has serious implication in the realization of the present educational policy that emphasizes technological literacy. If teachers of vocational subjects such as home economics do not have resources to teach their students, virtually students may not be able to completely acquire the skill. This is further supported by Oviawe and Uwameiye who reported that dearth of vital resources is evident in the high rate of failure in the vocational subjects. They also asserted that effective teaching of any science subject depend on the use of good laboratories.

\section{Conclusion}

The poor performance of students in public examination has been an issue of public interest. For instance, the Science Teachers Association (STAN) has over the years considered ways of improving students' performance in Science subjects. This research has however provided empirical evidence useful for improving the teaching and learning of home economics at the junior secondary schools which is the foundation for all branches of home economics (foods \& nutrition, clothing \& textiles and home management). It is worthy to note that what students perceived as conducive learning environment has positive impact on their interest and performance in various subjects. The home economics teacher and the students need good teaching and learning environment which is within their power to create and enforce for the effective teaching and learning of the subject since it is one of the vocational subject that can equip individual for self reliance. The importance of acquisition of vocational skills in a developing economy cannot be overemphasized; therefore, students should be motivated with highly equipped laboratories which can greatly enhance their interest and participation in home economics classes.

\section{Recommendations}

Based on the findings, the following recommendations were proffered.

- A well furnished home economics laboratory should be provided in public secondary schools in Edo state.

- All Teachers of home economics at various levels should create a good learning environment that is capable o motivating students to participate in home economics lessons.

- Government should provide conducive learning environment in all public secondary schools and also monitor private schools, set standards for all schools to comply or close them.

\section{References}

[1] Anene, O., (2002), Problems of Wastage in Home Economics Education in Nigeria in S.O, Osifo.P.O.E. Nwaokolo, Refocussing Education in Nigeria. Benin City; DaSylva. Influence 232-238.

[2] Ayankoha, E.U1991. An Approach for Improving the Effectiveness of Home Economics as Textiles and Clothing in Anambra State secondary Schools. Nigeria Vocational Journal.

[3] Burden, R., and Fraser B.J., (1993); Use of Classroom Environment Assessment in Schools Psychology, A Braish Perspective Psychology in School 30,pp232 -240

[4] Dorman, J.P, Fraser, R.J., \& Bobbie C.J., (1997); Relationship between School level and Classroom level Environment in Secondary Schools Journal of Educational Administration 35 pp74-91

[5] Fisher, D.L, Fraser, B.J and Wubbel, T., (1993); Inter personal Teacher Behaviour and School Environment. In the Wubbel and J. Levy Eds. Do you know what you look like Interpersonal Relationship in Education pp 103-112 London; Faimer Press. 
[6] Goodlord, (1984), A Place called School Prospects for the future. New York McGregraw Hill Book Co.

[11] Imariagbe, K.O., (2002). Redirecting Vocational and Technical Education in Nigeria In S.O, Oriafo G. C. Igborgbor Eds. Refocusing Education in Nigeria. Benin City. DaSylva.Influence.232-238

[12] Jegede, O.J., \& Fraser, B.J. 1994 Altering Socio Cultural Beliefs Hindering the $\mathrm{L}$ earning of Science Instructional Sciences 22,137-152.

[13] Koreau, Y.K. (2004). Educational Crisis Facing Nigerian Secondary Schools and Possible Solutions being a paper presented at the Faculty of Education, University of Ibadan.

[14] Mbah, P.E., (2001), Bringing Gender Gap in Home Economics Discipline, Implication for Curriculum Development, Akoka Journal of Pure and Applied Science, 2(1) 19-29.

[15] Mbah, P.E., (2003). Effect of two instructional methods on Junior Secondary School Home Economics Students Academic Performance in Lagos State. Ph.D. Thesis University of Benin, Unpublished.

[16] Nbina, J.B., (2012), Analysis of Poor performance of Senior Secondary Students in Chemistry in Nigeria. An International Multidisciplinary Journal, Ethiopia Vol 6 (4 Serial No 27.Pp324-334.

[7] Ogunbiyi, C. (1985). Material Production Project: Ibadan Heinmann Education books Nigeria Ltd.

[8] Ogwo B.A, Oranu, R.N, 2006, Methology in Formal and Formal and Non Formal Technical and Vocational Education .Enugu, Ijejas Publishers Company.

[9] Okeke, B. C 2006. Enhancing Enrolment in Vocational Programmes in Coiieges of Education in Delta States of Nigeria. International Journal of Educational Research and Development.11 72-89.

[10] Osisfo, G.A.T. 2004, Professional Obligations of Home Economics Towards a Better National Development in the 21st Century .In A.O Noah, D. Shonibere, A .Ojo EdsCurriculum Implementation and Professionalization of Teaching in Nigeria; lagos; pp 305-314.

[17] Owolabi, E.A., (1991). Home Economics Programs in Oyo State Secondary Schools. Journal of Consumer Studies and Home Economics. 15; 95-105.

[18] Tanvi J., (2010). How Environment Factors Affects our learning process. www.preservarticles.com/2011082912.

[19] Uko-Aviomoh E.E. 2005.Evolving a Dynamic Curriculum for Home Economics in Nigerian Schools. In S.O. Oriafo, G.C. Edozie. D.N Ezeh Eds; Curriculum Issues in Contemporary Education, Book in Honour of Professor Mrs Ebele Maduewesi Benin City; Dasyva Influence.

[20] Uwameiye, R., Oviawe, J.I., (2010). Availability of Human and Material Recourses for Teaching Blocklaying and Concrete Works in Technical Colleges of Edo State. Ebonyi Technology and Vocational Education Journal 1(1) 37-47. 